\title{
Financial Technology and Financial Inclusion of Small and Medium Enterprises in Kabati Market Kitui County, Kenya.
}

Agelyne, Muthengi, Salome M. Musau

To Link this Article: http://dx.doi.org/10.6007/IJARBSS/v11-i4/9679

DOI:10.6007/IJARBSS/v11-i4/9679

Received: 08 February 2021, Revised: 10 March 2021, Accepted: 26 March 2021

Published Online: 15 April 2021

In-Text Citation: (Agelyne \& Musau, 2021)

To Cite this Article: Agelyne, M., \& Musau, S. M. (2021). Financial Technology and Financial Inclusion of Small and Medium Enterprises in Kabati Market Kitui County, Kenya. International Journal of Academic Research in Business and Social Sciences, 11(4), 362-377.

Copyright: (C) 2021 The Author(s)

Published by Human Resource Management Academic Research Society (www.hrmars.com)

This article is published under the Creative Commons Attribution (CC BY 4.0) license. Anyone may reproduce, distribute, translate and create derivative works of this article (for both commercial and non-commercial purposes), subject to full attribution to the original publication and authors. The full terms of this license may be seen

at: http://creativecommons.org/licences/by/4.0/legalcode

Vol. 11, No. 4, 2021, Pg. 362 - 377

Full Terms \& Conditions of access and use can be found at http://hrmars.com/index.php/pages/detail/publication-ethics 


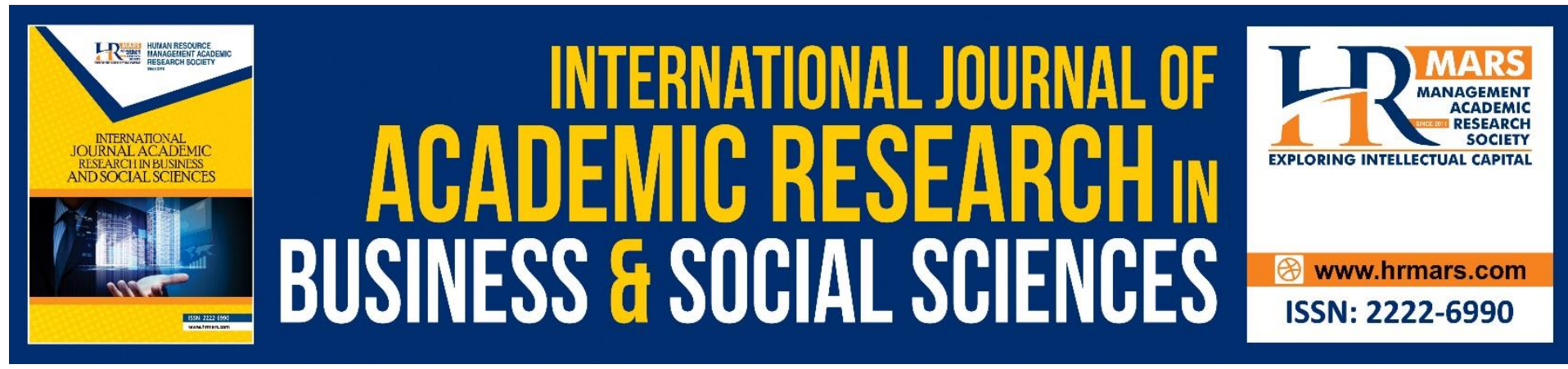

\title{
Financial Technology and Financial Inclusion of Small and Medium Enterprises in Kabati Market Kitui County, Kenya.
}

\author{
Agelyne, Muthengi, Dr. Salome M. Musau \\ Kenyatta University Department of Accounting and Finance, School of Business. \\ Email: kaniniangeline15@gmail.com
}

\begin{abstract}
The paper intents to establish the effect of financial technology and financial inclusion of Small and Medium Enterprises in Kabati market Kitui county, Kenya. Increase of financial access to individuals and other organizations has been due to successfully launched services of financial technology and financial institutions. Despite this development, access to formal financial services like Agency banking, M-Pesa services, online banking and Google play store services (Loan Apps) in small and Medium Enterprises in Kenya is still low. The paper is anchored on Pecking Order Theory (POT), Theory of Asymmetric Information, Technology Acceptance Model (TAM), Relationship Lending Theory (RLT), and Financial Intermediation Theory. The paper is informed by primary data obtained from Kabati market SMEs by Questionnaires. The study establishes that Financial technology have significant effect on financial inclusion of SMEs. The study recommended that the government should promote and support FinTech strategies such as Agency banking, M-pesa services, online banking and Money Lending Apps, since they facilitate the provision of financial services faster and in a more convenient and efficient manner, while still providing employment opportunities in areas that are underserved by traditional financial institutions as well as increased loyalty and profit for the FinTech companies hence leading to development of our country leading to the achievement of one of the four big agendas of vision 2030.
\end{abstract}

Keywords: Financial Technology, Financial Inclusion, Small and Medium Enterprises.

\section{Introduction}

Financial technology is a means by which opportunities are provided, through the reduction of costs of providing financial services to promote financial inclusion (Asian Development Bank, 2014). Financial inclusion is a means by which financial services are made affordable and available at reasonable costs to all businesses and individuals, regardless of their business size and net worth (Demirgüç-Kunt et al., 2015). On a global basis and mostly in developing and emerging economies, small and medium enterprises survive by their cash flow and face challenges in accessing affordable financing. The situation has made the banks and other financial institutions to under-serve the SMEs segments, due to risk optics and the absence of credit data, and cost profile (Alexander, 2017). A big percentage of adults who are at their working age have lacked access to financial services which have been a global policy concern 
(Mutegi \& Phelister, 2013). Financial inclusion aims at the provision of financial services and as well as help people with improved ways of maintaining resources and building financial abilities.

In Africa, Digital finance was first developed by the innovation of mobile money which is indicated as the first phase. The second phase of developing digital finance is being focused now on which they are aiming at individual resource management, individual and business insurance, and increasing accessibility to external finance by SMEs. M-pesa and mobile money startups are said to be the next generation of financial technology in Sub-Saharan Africa (Fintech Africa, 2018). A study done by Nwanko and Nwanko (2014) asserts that in the developing world, the majority are excluded in accessing financial services. The financial sector in these countries considers poor people as not viable customers because of their smaller transaction sizes while the majorities living in rural areas are underserved by financial institutions. Africans country Global Findex Database (2017) reports mobile money has the potential to drive financial inclusion. Regionally, there has been an increase of adults with an account as from 2014.

In Kenya, a survey done by KNBS reported that approximately 400,000 MSMEs closed down before gaining a second year of experience which raised a concern of sustainability in this sector (KNBS, 2016). They reported that 2.2 million SMEs closed down between 2010-2016. Kenya is one of the nations where financial technology has been improved through the mobile money system which includes M-Pesa services, agency banking and online transactions services (Mbiti \& Weil, 2011). The landscape of financial inclusion in Kenya has increased with $56.2 \%$ since the year 2006 up to date, though exclusion lessened down with 30.3\% from 2006 to date (Fin Access, 2019). Kenya's financial inclusion landscape has transformed since 2006. (FinAccess, 2019). There has been a mark of decline in the transformations between the rural and urban centers, rich and poor people and as well as between men and women. The growth of ICT, Government support and initiative, and mobile money usage brought out all these disparities.

The financial services should be provided in a way that they are available, affordable, adequacy, and accessible to excluded groups in the society with minimum standards of consumer protection by use of financial technology. This can be achieved if the government keeps a pace and provide solutions for risks associated with the delivery of financial technology-enabled services, the financial inclusion curve for our country will change for better in ten years to come and thus integrate digital payments to benefit all citizens regardless of their wealth status (Global Findex Database, 2017).

\section{Statement of the Problem}

Financial inclusion plays a dynamic role in Small and Medium Enterprises as it's recognized by policymakers as an economic actor to achieve poverty alleviation and sustainable growth. SMEs play a main role as it contributes in the achievement of four big agendas in vision 2030, as a key growth driver on development blueprint which seeks to convert our nation into a developed middle-income country, by provision of standard life to all people within the nation by the year 2030 (KNBS, 2015; CBK, 2016). To achieve this, the Kenya Association of Manufacturers and Government of Kenya have initiated and implemented several reforms. The Central Bank of Kenya in conjunction with financial institutions, has worked on launching a financial infrastructure on support of SMEs. Despite increased development of fintech, government initiatives and support increased execution of several restructurings by Kenyan government and support of financial infrastructure by CBK and financial institutions, some 
SMEs still face challenges of being financially excluded. Even though several studies were carried out on SMEs financial performance, they failed to empirically evaluate financial technology and financial inclusion of Small and Medium Enterprises in rural areas in Kenya, hence creating an empirical gap, which is the main focus of the study earlier studies seem to have ignored.

\section{Literature Review \\ Theoretical Review}

The theoretical review presents the theoretical foundations for the rest of the project. This study anchored on Pecking Order Theory, Theory of Asymmetric Information, Technology Acceptance Model, Relationship Lending Theory, and Financial Intermediation Theory. Since external financing is more expensive, Pecking Order Theory was used to explain how SMEs finance with internal funds first, followed by debt, and equity. Due to informational asymmetries between security holders and managers. Theory of asymmetric information explains how having more information in one agent between borrowers and lenders affect lending to SMEs. Technology acceptance models were used to explain how people accept and use technology depending on the availability of certain factors. Relationship lending theory established factors contributing to a successful quality lending index in SMEs. Financial intermediation theory used to determine how financial technology has led to increased SMEs financial inclusion leading to economic development.

\section{Empirical Review}

SMEs are essential businesses at both local and global scales because they offer people livelihoods and source of income. Developing countries face issues that limit SMEs development mostly due to difficulties in the adaptation of financial technology (Edward, 2011). Cost of using foreign technological equipment in SMEs is expensive and business owners use foreign licenses instead of the local patent due to the difficulty in acquiring ownership rights (Mlady, 2016). Developed countries are superior when it comes to technological advancements hence; they retain a competitive benefit over developing countries. SMEs are increasingly adapting to technological innovations in developing countries (Nganga \& Mwachofi, 2013). SMEs should invest in technology because of the competitive nature of the business industry. It was revealed by Terzi (2015) that financial inclusion is an effective program for financial literacy which involves increasing the knowledge of financial elements and how to use financial services. It sets a big gap between poor and rich people because it enables people to evaluate profits and losses. 


\section{Conceptual Framework}

Independent variables

Dependent variable

(Financial Technology)

Agency banking services
- Deposit of money
- Withdrawal of money
- Funds transfer
- Opening an account
- Balance inquiry

M-Pesa services

- Deposit money

- Withdraw money.

- M-shwariloans.

- Transfer money.

- Pay for goods and services.

- Fuliza

Online Banking services.

- Funds transfer.

- Ppayment of bills.

- inquiries

- Access to account

Google play store services

- Access to loans

- Access to financial planning tools

- Free inquiries and advice

Source: Researcher (2019)

Figure 1: Conceptual Framework

\section{Research Methodology}

This study adopted Descriptive Cross-sectional studies design. Descriptive Cross-sectional studies design, is a way by which data is collected from a certain population in a moment of time and thus used to present the features of the population at a point in time (Kothari,2008). Facts in this study are that a research data of the study was conducted at a point and respondents cut across different groups. The target population of the study was 502 SMEs in Kabati market as indicated by (appendix III). The target of the sample size of 223 SMEs was used and the respondents were the SMEs owners, Managers or the immediate supervisor. This study adopted the stratified random sampling method. In this sampling method, the researcher divided the entire population into strata and thus a sample was selected from each stratum. These enabled the researcher to select a sample size of 223 SMEs in a population of 502 SMEs in Kabati market to participate in the study. Sample size was selected by help of sampling formula $n=N /\left(1+N(e)^{2}\right)$ by Yamane (1967). Where by $n=$ sample size, $N=$ Population 
size, $\mathrm{e}=$ level of precision. Reason for the researcher to use this sampling method was because the target population was significantly heterogeneous. Then simple random sampling was used to select samples from every stratum.

Primary data was used for this study by administering both closed and open-ended questionnaires. Bolarinwa (2015) stated that research questionnaires are the most suitable tools for collecting data. From this assertion, the researcher collected data from respondents by use of well-structured questionnaires. Reason for using questionnaires in this study was to help in increasing speed for data collection and provide high level of objectivity. The questionnaire captured data which was relative to respondents' background and data regarding the dependent variable and independent variable. Closed ones had pre-determined answers resulting to quantitative data and open-ended gave respondents free will to answer resulting to qualitative data. Researcher used descriptive statistics and inferential statistics to analyze the collected data. The descriptive analysis contained frequencies and percentages for analyzing the demographic data of respondents. Then independent and dependent variable analyzation was done through the application of standard deviation and means. Inferential statistics used in analyzing data included correlation and multiple linear regression analyses. Multiple linear regression analyses and correlation analyses were used to measure the presence of a relationship between two quantitative variables (Gogtay and Thatte, 2017). This helped in discovering the relationship between the variables and their contribution to the study. Tables, figures, and pie charts were used to present data of the research findings. The study used ANOVA to calculate the level of variability within the regression model through the F-test and test the Null hypotheses. Regression was undertaken at $5 \%$ level of significance of the model. The study also adopted Multiple linear regression to establish the relationship between and financial technology services and products (Online banking, $M$ Pesa, Agency Banking and Loan Apps) towards financial inclusion of SMEs in Kabati market. Regression equation was; $Y=60+b 1 X_{1}+62 X_{2}+b_{3} X_{3}+b_{4} X_{4}+\varepsilon$

Whereby; $Y=S M E s$ financial inclusion, $B_{0}=$ constant (value of the dependent variable at zero value of independent), $X_{1}=$ Agency banking services, $X_{2}=$ M-Pesa services, $X_{3}=$ Online banking services, $X_{4}=$ Google play store services, $\varepsilon=$ Error Term (sampling measurement and coverage errors) and $b_{1}, b_{2}, b_{3}, b_{4}$ represents regression coefficients of independent variables.

\section{Results and Discussion}

The study sought to establish financial technology and financial inclusion of Small and Medium Enterprises in Kabati market Kitui, County. The findings were presented, interpreted and analyzed through use of means, frequencies, standard deviation, Cronbach alpha coefficients of reliability, correlations and regression of analysis.

\section{Results for Response Rate}

Table 4.1 is a summary of response. The study response rate was $86 \%$ which according to Mugenda and Mugenda (2003), response rate of $50 \%$ is indicated as adequate, $60 \%$ as good indicator and $70 \%$ very good indicator. Therefore, the response rate of this study was characterized to be very good indicator and thus sufficient. 
Table 4.1 Response rate

\begin{tabular}{|l|c|c|c|c|}
\hline Category of Respondents & $\begin{array}{l}\text { Questionnaires } \\
\text { Issued }\end{array}$ & $\begin{array}{l}\text { Questionnaires } \\
\text { Rreturned }\end{array}$ & $\begin{array}{l}\text { Percentage } \\
\text { issued }\end{array}$ & $\begin{array}{l}\text { Percentage } \\
\text { returned }\end{array}$ \\
\hline $\begin{array}{l}\text { SMEs } \\
\text { owner/manager/supervisor }\end{array}$ & 223 & 192 & $100 \%$ & $86 \%$ \\
\hline
\end{tabular}

Source: study data 2019

\section{Reliability Test}

In order for study questionnaire to measure what its intendent to measure in the research study, pilot test was carried out before using the study questionnaires in the actual data collection. Summary of reliability test was presented in table 4.2.

Table 4.2 Reliability statistics table

\begin{tabular}{|c|l|c|}
\hline & Reliability statistics & \\
\hline Cronbach's alpha & $\begin{array}{l}\text { Cronbach's alpha based on } \\
\text { standardised items }\end{array}$ & No. of items \\
\hline .823 & .834 & 5 \\
\hline
\end{tabular}

\section{Source: study data 2019}

Variables which give out a Cronbach's coefficient value above 0.70 according to (Mohsen, \& Reg, 2011) are considered reliable in the questionnaire.

Table 4.3 Reliability Test Table

\begin{tabular}{|l|c|l|l|l|l|}
\hline & & \multicolumn{2}{|l|}{ Item-Total Statistics } & & \\
\hline & $\begin{array}{l}\text { Scale mean if } \\
\text { Sariance if } \\
\text { item deleted }\end{array}$ & $\begin{array}{l}\text { Corrected } \\
\text { item } \\
\text { deleted }\end{array}$ & $\begin{array}{l}\text { Cronbachs } \\
\text { item total } \\
\text { correlation }\end{array}$ & $\begin{array}{l}\text { Squred } \\
\text { multiple } \\
\text { correlation }\end{array}$ & $\begin{array}{l}\text { Alpha if } \\
\text { item } \\
\text { Deleted }\end{array}$ \\
\hline $\begin{array}{l}\text { Agent banking } \\
\text { (iii) }\end{array}$ & 12.00 & 84.50 & .846 &. & .710 \\
\hline Mpesa (iii) & 12.00 & 95.50 & .807 &. & .726 \\
\hline $\begin{array}{l}\text { Online banking } \\
\text { (iii) }\end{array}$ & 12.00 & 155.50 & .031 & & .930 \\
\hline $\begin{array}{l}\text { Google Play app } \\
\text { lenders (iii) }\end{array}$ & 12.00 & 118.00 & .883 &. & .746 \\
\hline $\begin{array}{l}\text { Financial } \\
\text { inclusion (iii) }\end{array}$ & 12.00 & 109.50 & .767 &. & .749 \\
\hline
\end{tabular}

\section{Source: study data 2019}

The Cronbach's Alpha for the 5 items were above 0.7 which implied that they had high level of internal consistency. A value greater than 0.7 is considered acceptable in research questions thus in this case all questionnaires were acceptable.

\section{Respondents Demographics}

Characteristics of respondents in researches have a significant role in expression of whether individuals in the study are a representative sample of target population. The study background information regarded respondents Gender, Age distribution, education and respondent's year distribution of business experience. 


\section{Gender of Respondents}

Gender is state of being a male or a female. Results indicated that women are still slightly behind men when it comes to acquiring agent banking services, M-pesa services, online banking services and google play store app lenders services. Therefore, this indicates that payment ability, savings ability and credit accessibility of women is low compared to men (Karanja 2011).

\section{Age of Respondents}

Age in research helps the researcher in indicating level of maturity of the respondents. From the study results indicated that individuals in the 31-40 age bracket have a higher exposure to opportunities with regards to accessing financial services and products. Individuals in the 21-30 age brackets are still behind when it comes to financial inclusion (Teeples \& Glyers 2007).

\section{Level of Education for The Respondents}

level of education of SMEs owners in Kabati market disables them from being financially included. This is in agreement with Antoine and Leo (2017) who states that most poor and non-educated people are the ones who do not benefit from this financial technology banking system because they are not capable of receiving frequent and faster remittances Simply their level of education limits, them from acquiring banking services, M-pesa services, online banking services and google play store app lenders services this dis enables them in payment ability, savings ability and credit accessibility thus less financially included.

\section{Years in Which the Business Has Been Operating}

The findings indicates that the more the years increased enterprises kept on closing down and this might be due to lack of accessing banking services, M-pesa services, online banking services and google play store app lenders services which led them in inability in making payments, savings inability and in ability in accessing credit which led to low and low financial inclusion on the SMEs leading to closure of the enterprises.

\section{Descriptive Statistics}

Respondents classified their opinions in respect to the use of Agency banking services, $\mathrm{M}$ pesa services. Online banking services, Google Play Store app lenders services in their business operation, to employees and customer's service and financial inclusion of SMEs. Respondents agreement to the statements were classified on a Likert scale.

\section{Agency Banking Services}

Findings from analyzed results implied that Agent banking services are the most preferred and used by SMEs in kabati market because they are readily available and nearly located in the market and this has led to increased financial inclusion on SMEs within the market. This agrees with Kinyanjui (2011) who states that banking Model has helped in fostering financial inclusion in countries that are evolving. The study also established the most commonly used Agency banking, results indicated that equity bank agents are readily established and available to the SMEs for use leading to increased financial inclusion to them. Other banks should establish their agencies in rural areas so as to improve on financial inclusion of SMEs in rural areas. 


\section{M-Pesa Services}

The results implied that M-pesa services has a positive impact on financial inclusion of SMEs since they are able to acquire the financial services to the average. This agrees with Joseph (2018) who states that in Kitui County M-Pesa technology has a significant impact on SMEs financial inclusion. It was also found that, majority of SMEs in Kabati market used M-shwari to finance their business because they found it easy to save in M-shwari and it can be supported by all types of phones. Results also indicated that SMEs owners in Kabati market are able to make payments via lipa na $m$-pesa services as well as $m$-pesa transfer. This implies that $\mathrm{m}$-pesa services has high contribution in financial inclusion of SMEs.

\section{Online Banking Services}

Respondents agreed with all attributes of online banking services except for paying bills direct from bank account through online banking. Frame and White (2004) states its due to result of lack of wide reach of internet connectivity in rural areas as well as distribution of education levels and sensitization of the benefits of using internet banking hence low financial inclusion on SMEs.

\section{Google Play Store App Lenders Services}

Respondents pointed out that Access to Google Play Store app lenders enables them quick response during time of emergency and in need of funds. This is in agreement with study by (Edward, Delbridge, \& Munday 2011) stated that technology innovation assists SMEs through improving financial performance hence high contribution on their financial inclusion. Findings also indicated that Tala loans app lender is the most used app lender from Google Play Store.

\section{Financial Inclusion of SME's}

The study established the views of the respondents in regard to financial inclusion of SMEs in Kabati market. The results implied that the innovation of new financial technologies has enabled SMEs in payment ability, savings ability and credit accessibility thus increased financial inclusion.

\section{Inferential Statistics \\ Correlation Analysis}

The study used Pearson correlation analysis to establish the relationship between financial technology and financial inclusion of SMEs. Table 4.4 Results indicated that correlation is strongly positive implying that there exists a positive relationship between financial inclusion and financial technology variables under study. The correlation values were statistically significant at 0.05 level of significance. 
Table 4.4 Pearson Correlation Analysis

\begin{tabular}{|c|c|c|c|c|c|}
\hline & $\begin{array}{l}\text { Financial } \\
\text { Inclusion }\end{array}$ & $\begin{array}{l}\text { M-Pesa } \\
\text { Services }\end{array}$ & $\begin{array}{l}\text { Agency } \\
\text { Banking } \\
\text { services }\end{array}$ & $\begin{array}{l}\text { Online } \\
\text { Banking } \\
\text { services }\end{array}$ & $\begin{array}{l}\text { Google Play } \\
\text { (LoanApps) }\end{array}$ \\
\hline $\begin{array}{l}\text { Financial } \\
\text { Inclusion }\end{array}$ & 1 & & & & \\
\hline M-Pesa Services & $.910 *$ & 1 & & & \\
\hline $\begin{array}{l}\text { Agency Banking } \\
\text { services }\end{array}$ & $.979 * *$ & $.944^{*}$ & 1 & & \\
\hline $\begin{array}{l}\text { Online Banking } \\
\text { services }\end{array}$ & $.962 * *$ & $.764^{*}$ & .562 & 1 & \\
\hline $\begin{array}{l}\text { Google Play } \\
\text { (LoanApps) }\end{array}$ & $.973 * *$ & $.678^{*}$ & .782 & $.997^{*}$ & 1 \\
\hline
\end{tabular}

Source: Researcher (2019)

**. Correlation is significant at the 0.01 level (2-tailed).

*. Correlation is significant at the 0.05 level (2-tailed).

Correlation between Agency Banking and Financial Inclusion of SMEs from table 4.4was average positive significant relationship. The correlation coefficient obtained was 0.979 which was found to be significant at $p<0.05$ level of significance. This indicates that Agency Banking services were significant determinant of financial inclusion of SMEs of in Kabati market Kitui County. Hence increased use of Agency Banking services leads to increased financial inclusion of SMEs. From table 4.4 above the study established an average of a positive significant relationship between Correlation between M-Pesa and Financial Inclusion of SMEs ( $r=.910$, $\mathrm{p}<0.01$ ). This showed that there was a direct relationship between $\mathrm{M}$-pesa and Financial Inclusion of SMEs. The successful financial inclusion of SMEs is dependent on the use of Mpesa services.

From table 4.4 the results showed the presence of average positive significant between Online Banking and financial inclusion of SMEs $(r=.962, p=0.01)$. This indicated direct linear relationship, meaning increase on use of Online Banking services results to increase in Financial Inclusion of SMEs. Fromtable 4.4 above the results showed the presence of average positive significant between Google Play Store and financial inclusion of SMEs $(r=.973$, $p=0.01$ ). henceforth, a direct linear relationship, meaning an increase in the use of Google Play Store app lenders results to increase in Financial Inclusion of SMEs. Therefore, in order to enhance financial inclusion of SMEs in Kabati market, Kitui county, there should be an increase in the use of Google Play Store app lenders services.

\section{Model Summary}

The study sought to determine the proportion of variation in the dependent variable that can be attributed to the independent variable. The findings of the coefficient of adjusted determination $\left(R^{2}\right)$ were summarized in table 4.5 
Table 4.5Regression Weights for Overall Model

Model summary

\begin{tabular}{|c|c|c|c|}
\hline Model & R squared & Adjusted R square & Std Error of The Estimate \\
\hline 1 & 0.966 & 0.9465 & 0.16547 \\
\hline
\end{tabular}

a. Predictors: (Constant), agent banking (i), M-pesa (i) Google play services (i), online banking (i)

b. Dependent Variable: financial inclusion (i)

From table 4.5 above, the results of coefficient of determination of adjusted $\left(R^{2}\right)=0.9465$, which translates to $94.65 \%$. This implied that $94.65 \%$ of financial inclusion of SMEs in Kabati market, Kitui county could be explained by change on financial technology while $5.35 \%$ of the change of financial inclusion was attributed by other factors outside the study scope. These factors may include cultural beliefs, infrastructure and economic factors like law policies, wages, government activities and Tax rates.

\section{Analysis of Variance (ANOVA)}

The regression was undertaken at $5 \%$ level of significance and the alpha value compared to $p$-value to determine the significance of the model. The significant test results were summarized in table 4.6

Table 4.6 Significant Test Results

\begin{tabular}{|c|c|c|c|c|c|c|}
\hline \multicolumn{7}{|c|}{ ANOVA } \\
\hline \multicolumn{2}{|c|}{ Model } & $\begin{array}{l}\text { Sum of } \\
\text { squares }\end{array}$ & Df & $\begin{array}{c}\text { mean } \\
\text { squares }\end{array}$ & $\mathrm{F}$ & Sig. \\
\hline \multirow{3}{*}{1} & Regression & 20.812 & 4 & \multirow{3}{*}{$\begin{array}{r}5.203 \\
0.1428\end{array}$} & \multirow[t]{3}{*}{36.435} & \multirow[t]{3}{*}{0} \\
\hline & Residual & 1 & 7 & & & \\
\hline & Total & 21.812 & 11 & & & \\
\hline
\end{tabular}

a. Dependent Variable: financial inclusion (i)

From the results is can be observed that $(F=36.435 ; p<0.05)$ which is less than the level of significance alpha, therefore it was statistically concluded that the model is significant.

\section{Hypothesis Testing}

The study sought to test the hypothesis by relating the dependent and independent variables. The study employed T-test in testing of null hypotheses at $95 \%$ confidence level ( $p$ value $=0.05$ ) and results presented in table 4.7 . 
INTERNATIONAL JOURNAL OF ACADEMIC RESEARCH IN BUSINESS AND SOCIAL SCIENCES

Vol. 11, No. 4, 2021, E-ISSN: 2222-6990 ㄷ 2021 HRMARS

Table 4.7 Results for Overall Model

Coefficients

\begin{tabular}{|c|c|c|c|c|c|c|c|c|}
\hline \multirow{2}{*}{\multicolumn{2}{|c|}{ Model }} & \multicolumn{2}{|c|}{$\begin{array}{l}\text { Unstandardized } \\
\text { Coefficients }\end{array}$} & \multirow{2}{*}{$\begin{array}{c}\begin{array}{c}\text { Standardize } \\
\mathrm{d} \\
\text { Coefficients }\end{array} \\
\text { Beta }\end{array}$} & \multirow[t]{2}{*}{$\mathrm{T}$} & \multirow[t]{2}{*}{ Sig. } & \multicolumn{2}{|c|}{$\begin{array}{l}95.0 \% \text { Confidence } \\
\text { Interval for B }\end{array}$} \\
\hline & & $B$ & Std. Error & & & & $\begin{array}{l}\text { Lower } \\
\text { Bound }\end{array}$ & $\begin{array}{l}\text { Upper } \\
\text { Bound }\end{array}$ \\
\hline & (Constant) & 5.120 & 1.05 & & 9.975 & .000 & 5.120 & 5.120 \\
\hline & M-pesa (i) & -2.322 & 2.04 & -3.651 & -3.765 & .000 & -2.322 & -2.322 \\
\hline 1 & $\begin{array}{l}\text { Agency } \\
\text { banking (i) }\end{array}$ & .826 & .077 & 1.211 & .138 & .000 & .826 & .826 \\
\hline & $\begin{array}{l}\text { Online } \\
\text { banking (i) }\end{array}$ & 1.674 & .065 & 3.086 & 4.417 & .000 & 1.674 & 1.674 \\
\hline & $\begin{array}{l}\text { Google play } \\
\text { services (i) }\end{array}$ & 424 & .075 & .481 & 5.214 & .000 & .424 & .424 \\
\hline
\end{tabular}

The results of T-statistics shown in table 4.7 were employed to test the null hypothesis.

$\mathrm{H}_{01}$ : Agency banking services have no significant effect on financial inclusion of SMEs in Kabati market Kitui County.

The first objective of the study sought to establish the role of Agency banking services on financial inclusion of SMEs in Kabati market Kitui County and the findings are as shown in table 4.7. To achieve this objective a null hypothesis, $\mathrm{H}_{01}$, that Agency banking services have no significant effect on financial inclusion of SMEs in Kabati market Kitui County was formulated. In table 4.16 the coefficient of Agency banking services $\beta=0.826, p=0.000<0.05$ this shows a positive statistically significant relationship between Agency banking services and financial inclusion. Henceforth the null hypothesis that Agency banking services have no significant effect on financial inclusion of SMEs in Kabati market Kitui County was rejected at $5 \%$ level of significance. The findings indicate that the increased use of Agency banking services increases the financial inclusion of SMEs. The findings were in agreement with Mark (2015) who indicated that Agency banking has significance impact on financial inclusion in Kenya.

$H_{02:}$ M-Pesa services have no significant effect on financial inclusion of SMEs in Kabati market Kitui County.

The second objective of the study sought to determine the role of M-Pesa services on financial inclusion of SMEs in Kabati market Kitui County. And the findings are as shown in table 4.7. To achieve this objective a null hypothesis, $\mathrm{H}_{02}$, that $\mathrm{M}$-Pesa services have no significant effect on financial inclusion of SMEs in Kabati market Kitui County was formulated. In table 4.7 the coefficient of $M$-Pesa services $\beta=-2.322, p=0.000<0.05$ this shows a negative statistically significant relationship between M-Pesa services and financial inclusion. Henceforth the null hypothesis that M-Pesa services have no significant effect on financial inclusion of SMEs in Kabati market Kitui County was rejected at $5 \%$ level of significance. The findings indicate that the increased use of M-Pesa services decreases the financial inclusion of SMEs. Therefore, the 
findings were not in consisted with Joseph (2018) who found out that m-pesa technology has positive significant impact on financial inclusion.

$\mathrm{H}_{03}$ : Online banking services have no significant effect on financial inclusion of SMEs in Kabati market Kitui County.

The third objective of the study sought to establish the role of online banking on financial inclusion of SMEs in Kabati market Kitui County and the findings are as shown in table 4.7 To achieve this objective a null hypothesis, $\mathrm{H}_{03}$, that Online banking services have no significant effect on financial inclusion of SMEs in Kabati market Kitui County was formulated. In table 4.7 the coefficient of Online banking services $\beta=1.671, p=0.000<0.05$ this shows a positive statistically significant relationship between Online banking services and financial inclusion. Henceforth the null hypothesis that Online banking services have no significant effect on financial inclusion of SMEs in Kabati market Kitui County was rejected at $5 \%$ level of significance. The findings indicate that the increased use of of Online banking services increases the financial inclusion of SMEs. The findings were in agreement with study done by Donner and Escobari (2010) they found out that the role of online transactions is to increase the economic growth of business.

\section{Ho4: Google play store app lender services have no significant effect on financial inclusion of SMEs in Kabati market Kitui County.}

The fourth objective of the study sought Examine the role of Google play store services on financial inclusion of SMEs in Kabati market Kitui County and the findings are as shown in table 4.7. To achieve this objective a null hypothesis, $\mathrm{H}_{04}$, that Google play store app lender services have no significant effect on financial inclusion of SMEs in Kabati market Kitui County was formulated. In table 4.7 the coefficient of Google play store app lender services $\beta=0.424$, $p=0.000<0.05$ this shows a positive statistically significant relationship between Google play store app lender services and financial inclusion. Henceforth the null hypothesis that Google play store app lender services have no significant effect on financial inclusion of SMEs in Kabati market Kitui County was rejected at $5 \%$ level of significance.

The findings indicate that the increased use of Google play store app lender services increases the financial inclusion of SMEs. The findings were in agreement with study done by Shaikh, Glavee-Geo and Karjaluoto (2017) they found that there is a relationship between the innovation of financial inclusion and promotion of digital banking culture in Pakistan.

\section{Multiple Linear Regression Equation}

The equation is of the form:

$$
Y=B_{0}+b_{1} X_{1}+b_{2} X_{2}+b_{3} X_{3}+b_{4} X_{4}+\varepsilon
$$

$Y$ represents SMEs financial inclusion

$B_{0}$ represents constant (value of the dependent variable at zero value of independent).

$B_{1}=$ Coefficient for Agent Banking services

$B_{2}=$ Coefficient for M-pesa services

$B_{3}=$ Coefficient for Online banking

$B_{4}=$ Coefficient for Google play store app lenders services

$\varepsilon$ represents Error Term (sampling measurement and coverage errors)

The multiple linear regression equation model therefore becomes;

$Y=5.120+0.826 X_{1}-2.322 X_{2}+1.674 X_{3}+0.424 X_{4}+0$ 


\section{Conclusion}

The study concludes that study Most SMEs holders in Kitui county are now able to access financial services, from access to credit to financial planning tools, with the help of online banking and mobile money platforms thus driving business growth and further enhancing financial inclusion. The study also concludes that agency banking and M-Pesa have provided employment opportunities to the SMEs further enhancing financial inclusion among the people. The study also concludes that the financial services offered by the FinTechs are appealing and have a significantly positive adoption within this segment of business holders since they lead to faster access to financial services and thus increased financial inclusion.

\section{Recommendations}

the study recommends that financial institutions should establish more banking agents in rural areas since they are the most preferred and used by SMEs. SMEs prefer them because they are readily available, extended opening hours and nearly located in the market and this has led to increased financial inclusion. The study also recommends that, Online banking services contributes much on financial inclusion. Therefore, people should rely online banking services when making fund's transaction and paying bills. It was found that online banking services benefits users by being convenient in terms of time, prevents theft of money that arises in the business premises, one can access account balances anytime and thus helps one track transactions easily and at any time. Thus, the cost of transactions needs to be lowered since online banking has the most significant effect on the increase of the financial inclusion index on SMEs. The study recommends that the government to contribute in promotion and support of FinTech tools since they facilitate in the provision of financial services faster and in a more convenient and efficient manner in areas that are underserved by traditional financial institutions. The study also recommends that government to provide licenses at low fee so as for FinTechs to have more products and services at an affordable fee targeting SMEs since this group does not necessarily always have access to financial products provided by conventional institutions and this will lead to greater financial inclusion to SMEs.

\section{Suggestion for Further Research}

This study was limited to finding the effect of four Financial Services Delivery Technologies on financial inclusion of SMEs. the study recommends that future studies be focused on evaluating the extent to which Fintech have affected the adoption of conventional financial institutions' products in the sub-urban areas, and also in general the effects of the Fintech in society.

\section{References}

Alexander, R. (2017). SMEs and financial inclusion globally. Journal of Financial Economics, Vol. 98(3), 626-650.

Antoine, D., \& Leo, V. (2017). The Middle East toward Incubator Benefits: Case Studies. ICBMEF 2012: International Conference on Business, Management, Economics and Finance, Dubai, UAE, page 29-31.

Asian Development Bank. (2014). Capital Market Financing for SMEs: A Growing Need in Emerging Asia. Regional Economic Integration Policy Research Working Paper, 2984.

Bolarinwa, O. (2015). Principles and methods of validity and reliability testing of questionnaires used in social and health science researchers. Niger Postgrad Medical Journal 22:195-201 
Central Bank of Kenya. (2016). Bank Supervision Annual Report. Nairobi, Kenya.

Central Bank of Kenya. (2016). Financial inclusion for the unbanked and SMEs. Nairobi, Kenya. County Government of Kitui. (2016). Annual Development Plan, Nairobi, Kenya.

Demirgüç-Kunt, A., \& Klapper, L. (2012) "Measuring Financial Inclusion: The Global Findex Database" Policy Research Working Paper, No. 6025.

Demirgüç-Kunt, A., Klapper, L., Singer, D., \& Van Oudheusden, P. (2015). The Global Findex Database: Measuring Financial Inclusion around the World. World Bank Policy Research Working Paper No. 7255.

Edwards, T., Delbridge, R., \& Munday, M. (2011). Linking innovative potential to SME performance: An assessment of enterprises in industrial South Wales Procedia - Social and Behavioral Sciences, 195, 334-342.

Fin Access. (2019). Financial inclusion in Kenya: Results and analysis. Nairobi: Fin Access.

Gogtay, N. J., \& Thatte, U. M. (2017). Principles of correlation Analysis, Journal of The Association of Physicians of India, 65 (March), pp. 78-81.

Global Findex Database. (2017). Measuring Financial Inclusion and the Fintech Revolution. World Bank: Washington, DC.

Joseph, K. (2018). Effect of mobile technology on financial inclusion in Kitui County, Kenya. Moi university published MBA project.

Kashangaki, J. (2014). Transforming SME Finance. Project Briefing Note 1, GrowthCap/FSD Kenya.

Kenya. (2013) Kenya vision 2030: Second Medium Term Plan 2013 - 2017, Nairobi www.vision2030.go.ke.

Kenya National Bureau of Statistics. (2016). Micro, small and medium establishment survey Basic. Nairobi: Kenya.

Kenya National Bureau of Statistics. (2019). Strategic Plan on deepening inclusion of Micro, small and medium 2006-2019. Nairobi: Kenya National Bureau of Statistics.

Kothari, C. (2008). Research Methodology: Methods \& Techniques, $3^{\text {rd }}$ edition. New age International Publishers. New Delhi.

Kinyanjui, K. (2011). Money markets, agency banking, run into hurdles. Business Daily Monday, June 11, 2011.

Mohsen, T., \& Reg, D. (2011). Making Sense of Cronbach's Alpha. International Journal of Medical Education. 2011; 2:53-55.

Mlady, L. (2016). Consumer Protection Issues for Digital Financial Services in Emerging Markets. Banking \& Finance Law Review, 31(2), 389-401.

Mbiti, I., \& Weil, D. (2011). Mobile Banking: The impact of M-PESA in Kenya. National Bureau of Economic Research, Working Paper No. 17129.

Mutegi, K., \& Phelister, N. (2015). Financial literacy and its impact on loan repayment by small and medium entrepreneurs. International journal of economics, commerce, and management the UnitedKingdom Vol. 6 (12), 58 - 76.

Mugenda, O. M., \& Mugenda, A. G. (2003). Research Methods: Quantitative and Quantitative approach. Nairobi: ACTS press.

Mugenda, B. (2008). Social Science Research: Theory and Principles. Nairobi. Applied Research and Training Services.

Nganga, S. I., \& Mwachofi, M. M. (2013). Technology Adoption and the Banking Agency in Rural Kenya. Journal of Sociological Research.Vol.4(1). 
Nwanko, O., \& Nwanko, N. (2014). Sustainability of Financial Inclusion to Rural Dwellers in Nigeria: Problems and Way Forward. Research Journal of Finance and Accounting, 5(5); 24-31.

Terzi, N. (2015), Financial inclusion and Turkey. Academic Journal of Interdisciplinary Studies, 4(1), 269-276.

Yamane, T. (1967). Statistics, An Introductory Analysis, 2nd Ed., New York: Harper and Row. 